\title{
NOTES ON CONTRIBUTORS
}

JACQUELINE BEAUMONT is a visiting Research Fellow in the School of Humanities, Oxford Brookes University. She returned to full-time historical research in 1996 after retiring from the Civil Service. She has written on censorship of the British press during the South African War and is currently writing a book on the role of the press during the war.

JOHN BENYON was until 1998 Professor of History at the University of Natal, Pietermaritzburg. He has published on the mechanism of High Commissionership in South Africa, including Proconsul and Paramountcy in South Africa: The High Commission, British Supremacy and the SubContinent, 1806-1910 (1980).

HELEN CALLAWAY is a former Director of the Centre for Cross-Cultural Research on Women at Queen Elizabeth House in the University of Oxford. She is the author of Gender, Culture and Empire: European Women in Colonial Nigeria (1987), and co-editor of Anthropology and Autobiography (1992) and Caught Up in Conflict: Women's Responses to Political Strife (1986). She is currently writing, with Dorothy O. Helly, a biography of Flora Shaw/Lady Lugard.

BALASUBRAMANYAM CHANDRAMOHAN is Senior Lecturer in PostColonial Studies in the Faculty of Humanities at the University of Luton. He has also taught at universities in India, Algeria and Switzerland. His publications include A Study of Trans-Ethnicity in Modem South Africa: The Writings of Alex La Guma, 1925-1985 (New York, 1992). He is currently working on a history of Indian overseas writing, with special reference to indentured labour migration in the nineteenth and twentieth centuries.

GREG CUTHBERTSON teaches History at the University of South Africa, Pretoria. He has published in the fields of religious history, comparative USSouth African historiography and war and society. He is an immediate past editor of the South African Historical Journal and is an international contributing editor of the Journal of American History.

DOROTHY O. HELLY is Professor Emerita of History and Women's Studies at Hunter College and the Graduate School, City University of New York. Her published works include Livingstone's Legacy: Horace Waller and 


\section{NOTES ON CONTRIBUTORS}

Victorian Mythmaking (1987), Gendered Domains: Rethinking the Public and Private in Women's History (1992) and Women's Realities, Women's Choices: An Introduction to Women's Studies. With Helen Callaway she published 'Crusader for Empire: Flora Shaw/Lady Lugard', in N. Chaudhuri and M. Strobel (eds), Western Women and Imperialism: Complicity and Resistance (1992) and both are currently working on a full-length biography of Flora Shaw.

KEITH JEFFERY is Professor of Modern History at the University of Ulster at Jordanstown. His recent publications include 'An Irish Empire'? Aspects of Ireland and the British Empire (editor, Manchester University Press Studies in Imperialism, 1996) and A Military History of Ireland (joint editor, Cambridge pbk edn, 1997). He was the 1998 Lees Knowles Lecturer at Trinity College, Cambridge.

DONAL LOWRY is Senior Lecturer in History at Oxford Brookes University. A graduate of University College Dublin and Rhodes University, he has also taught at Rhodes University, University College Chester and the University of York. He has published articles and essays on Southern Rhodesia/Zimbabwe, loyalist and anti-colonial movements in the British Empire, and Irish foreign policy in the Commonwealth, 1922-49. He is currently engaged in a book-length study of ideological links between British colonies of settlement in the nineteenth and twentieth centuries.

FRANSJOHAN PRETORIUS is Professor of History at the University of Pretoria. He is the author of several books on the South African War, including Kommandolewe tydens die Anglo-Boereoolog, 1899-1902, which has received three non-fiction awards. An English edition, Life on Commando during the Anglo-Boer War, 1899-1902 was published in 1999. In 1998 he was awarded the Stals Prixe for Cultural History by the Suid Afrikaanse Akademie vir Wetenskap en Kuns, and he currently serves on the Central Committee for the Commemoration of the South African War.

CHRISTOPHER SAUNDERS is Associate Professor of History at the University of Cape Town. Educated at the University of Cape Town and the University of Oxford, he is the author of Making the South African Past (1988), Historical Dictionary of South Africa (1983, new edn 1998), Writing History (1992) and many articles on topics in South African and Namibian history. His special fields of interest include historiography, urban history and the recent political history of southern Africa.

IAIN R. SMITH is Senior Lecturer in History at the University of Warwick. He is the author of The Origins of the South African War (1996) and, with 


\section{NOTES ON CONTRIBUTORS}

Christopher Saunders, of the section on 'Southern Africa 1795-1910' in The Oxford History of the British Empire, volume 3 (1999).

MORDECHAI TAMARKIN is a graduate of the Hebrew University, Jerusalem, and of the School of Oriental and African Studies in the University of London, and is Professor of History at the University of Telaviv. His research areas include colonial and post-colonial Kenya, the decolonisation of Zimbabwe, ethnicity and the state in Africa, the late nineteenth-century Cape Colony and ethnic relations in post-Communist eastern Europe. His publications include The Making of Zimbabwe: Decolonization in Regional and International Politics (1990) and Cecil Rhodes and the Cape Afrikaners (1990). 